\title{
Specific radioimmunoassay of glucitol-lysine - application to lens proteins in streptozotocin-diabetic rats
}

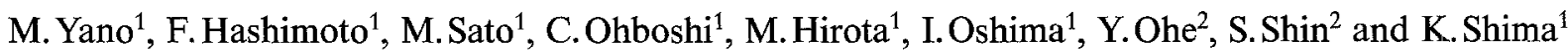 \\ ${ }^{1}$ Department of Laboratory Medicine, Tokushima University School of Medicine, and \\ ${ }^{2}$ Otsuka Assay Laboratories, Otsuka Pharmaceutical Co. Ltd., Tokushima, Japan
}

Summary. A radioimmunoassay using antibody against glucitol-lysine was developed to quantitate glycated proteins in the lens of diabetic rats. The amount of glycated protein was expressed as molar equivalents of reduced glycated hippuryl lysine $\left(\mathrm{Glc}_{\mathrm{RED}}\right.$-Hip-Lysine). Significant differences $(p<0.01)$ were found in the amounts of glycated protein in the lenses of rats with streptozotocin-induced diabetes (3.92 \pm $0.59 \mathrm{nmol} / \mathrm{mg}$ protein, $n=5$ ), those with streptozotocin-induced diabetes treated with insulin $(2.94 \pm 0.36 \mathrm{nmol} / \mathrm{mg}$ protein, $n=4)$ and normal rats $(1.23 \pm 0.22 \mathrm{nmol} / \mathrm{mg}$ protein, $n=5$ ). There was a significant correlation between the concentration of glycated protein in the lens and the $\mathrm{HbA}_{1 \mathrm{c}}$ level at the end of the 12 week experiment $(r=0.957, p<0.001)$. These results indicate that glycation of lens protein is parallel with the severity of diabetes in rats.

Key words: Glycation, diabetes, radioimmunoassay, glucitollysine.
Nonenzymatic glycation of plasma and lens proteins, collagen and various other proteins in the human body has been demonstrated in healthy subjects and to a greater extent in diabetic patients $[1,2]$. This glycation is due to condensation of glucose with amino groups of proteins to form Schiff's bases. The resulting labile aldimine may then either dissociate or undergo a slow Amadori rearrangement to form a more stable ketoamine [3]. Protein glycation has been reported to be increased in cataractous lenses of diabetic patients $[4,5]$ and rats [6], supporting the idea of a relationship between glycation of lens protein and cataract formation. However, experimental data that do not support this idea have been reported [7]. In these previous studies, glycated proteins were measured by rather unspecific and insensitive chemical methods, such as a colorimetric method $[4,5]$ or use of $\left[{ }^{3} \mathrm{H}\right] \mathrm{NaBH}_{4}$, which is highly reactive with the ketoamine linkage between a reducing sugar and the $\varepsilon$-amino group of lysine [7]. In this work we developed a radioimmunoassay (RIA) specific for glucitol-lysine residues. Then we used this assay to determine the amounts of glycated proteins in the lens of control and diabetic rats and the relationship between the extent of glycation of lens protein and the severity of diabetes mellitus.

\section{Material and methods}

\begin{abstract}
Animals
Male Wistar rats weighing approximately $300 \mathrm{~g}$ were fed ad libitum. Streptozotocin was injected at a dose of $65 \mathrm{mg} / \mathrm{kg}$ body weight into 9 rats via a jugular vein. Four weeks later 4 of these rats received Lente insulin s.c. at a dose of $12 \mathrm{U}$ daily in the evening until they were killed in week 12 . Five untreated littermates served as controls. Blood was taken from the jugular vein in weeks 0 and 12 for measurement of blood glucose and $\mathrm{HbA}_{1 \mathrm{c}}$. At the end of the experiment, after blood sampling, lenses were excised and frozen until use.
\end{abstract}

\section{Materials}

The following materials were used for development of a RIA for glycated protein: hippuryl-L-lysine (Hip-Lysine; the Peptide Institute, Inc., Osaka, Japan), bovine serum albumin (BSA) and low density lipoprotein (LDL; Sigma Chemical Co., St. Louis, Mo, USA), human serum albumin (HSA; Behring Institute, Mannheim, FRG), sodium cyanoborohydride $\left(\mathrm{NaCNBH}_{3}\right.$; Aldrich Chemical Co., Milwaukee, Wis, USA), glucose and sodium borohydride $\left(\mathrm{NaBH}_{4}\right.$; Wako Pure Chemical Industries Co., Osaka, Japan), and $\mathrm{Na}^{125} \mathrm{I}$ (New England Nuclear, Boston, Mass, USA).

\section{Radioimmunoassay of glycated protein}

Preparation of immunogen. Proteins were glycated and reduced by the method of Curtiss and Witztum [8] with slight modification. 


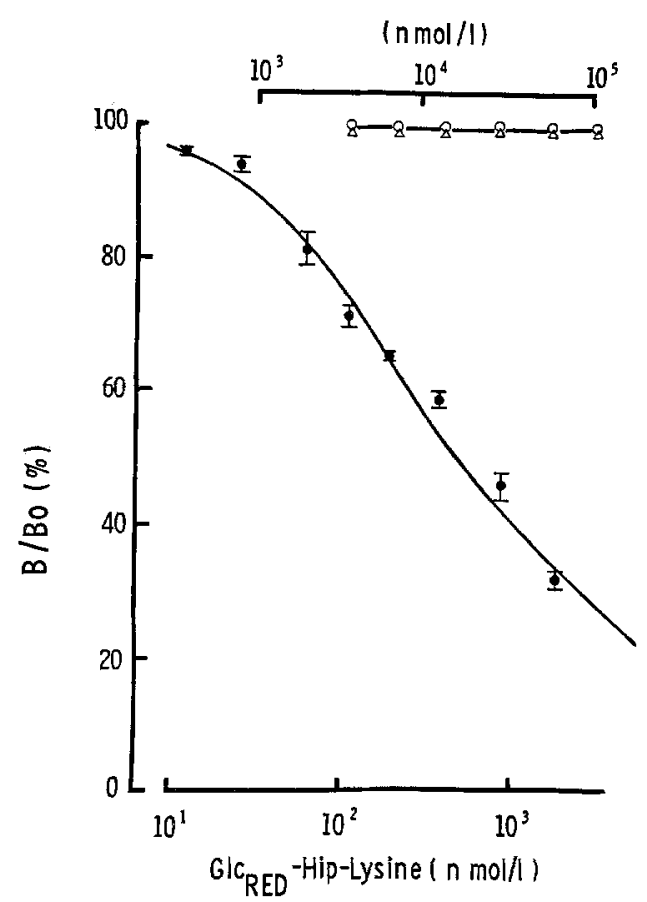

Fig. 1. Displacement of ${ }^{125} \mathrm{I}$-reduced glycated bovine serum albumin ( ${ }^{125} \mathrm{I}-\mathrm{Gl} \mathrm{C}_{\mathrm{RED}}$-BSA) from antibody against glucitol-lysine by reduced

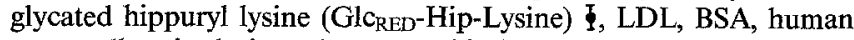
serum albumin, lysine, glucose, sorbitol $O \triangle---O \triangle$. Each point on

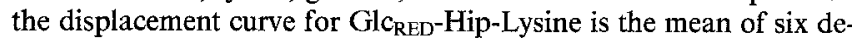
terminations. Bars represent $\pm S D$. $B_{0}$ and $B$ are radioactivities of the precipitate in the absence and the presence of Glc $c_{R E D}-H i p-L y s i n e$, respectively

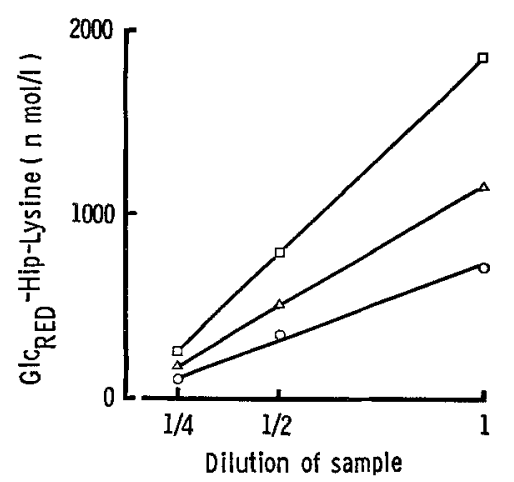

Fig. 2. Linear relationship between measured glycated protein for

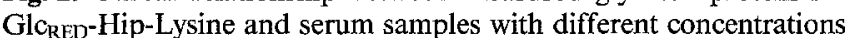
of glycated protein (low $O$, medium $\Delta$, high $\square$ ) diluted two- and four-fold with our buffer as described in Materials and methods

Briefly, $1 \mathrm{mmol} / 1$ of bovine LDL was dissolved in $10 \mathrm{ml}$ of $50 \mathrm{mmol} / 1$ phosphate buffer containing $0.15 \mathrm{~mol} / 1 \mathrm{NaCl}$ (PBS) and incubated with $80 \mathrm{mmol} / \mathrm{l} \mathrm{D}$-glucose in the presence of $200 \mathrm{mmol} / \mathrm{l}$ of freshly prepared sodium cyanoborohydride $\left(\mathrm{NaCNBH}_{3}\right)$ at room temperature for seven days. Then the mixture was acidified with acetic acid to stop the reaction, dialysed extensively against distilled water and lyophilised. BSA and HSA were also glycated by the same method.

\section{Preparation of reduced glycated ( $G c_{R E D}$ )-Hip-Lysine}

A solution of $200 \mathrm{mg}$ of Hip-lysine and $129 \mathrm{mg}$ of glucose in $10 \mathrm{ml}$ of a mixture of $\mathrm{H}_{2} \mathrm{O}$ and dioxane $(1: 1)$ was prepared and incubated with $100 \mathrm{mg}$ of $\mathrm{NaCNBH}_{3}$ at room temperature for 4 days. The reaction was stopped by adjusting the mixture to $\mathrm{pH} 3.0$ with acetic acid. The product was washed with $10 \mathrm{ml}$ of $100 \%$ methanol, evaporated to dryness, and purified by high performance liquid chromatography on a column of TSK $120 \mathrm{~T}$ (Toyosoda Co, Osaka, Japan). For elution, two solutions were prepared: $50 \mathrm{mmol} / 1$ trifluoroacetic acid in $90 \%$ acetonitrile (solution $\mathrm{A}$ ), and $5 \%$ acetonitrile (solution $\mathrm{B}$ ). The column was eluted with a linear gradient of solutions A and B at ratios of from 1:9 to $6: 4$ in $30 \mathrm{~min}$ at room temperature at a flow rate of $2 \mathrm{ml} / \mathrm{min}$. Fractions of eluate were collected every minute, and their absorbance at $280 \mathrm{~nm}$ was measured. Glc $c_{R E D}$-Hip-Lysine, which was eluted just before the elution position of authentic HipLysine, was collected and evaporated in a centrifugal concentrator. The recovery was $58.2 \%$ of the starting material by weight.

\section{Immunisation of rabbits with reduced glycated $\left(G l c_{R E D}\right)-L D L$}

Five rabbits were immunised s. c. with $100 \mu \mathrm{g}$ of $\mathrm{Glc}_{\mathrm{RED}^{-}} \mathrm{LDL}$ emulsified in complete Freund's adjuvant at 2-week intervals for 5 months.

\section{Radiolabelling of reduced glycated $\left(G c_{R E D}\right)-B S A$}

Glc $_{\text {RED }}$-BSA was iodinated with ${ }^{125} I-N a$ by the chloramine-T method [9]. The iodinated product was purified by gel chromatography on a column $(1.0 \times 60 \mathrm{~cm})$ of Sephadex G-50 developed with $50 \mathrm{mmol} / 1$ phosphate buffer, $\mathrm{pH} 7.4$, containing $0.15 \%$ gelatin and $0.01 \% \mathrm{NaN}_{3}$. The specific activity of the iodinated $\mathrm{Glc}_{\mathrm{RED}}-\mathrm{BSA}$ was about $8 \mu \mathrm{Ci}$ / $\mu \mathrm{g}$ protein.

\section{Radioimmunoassay procedure}

Each incubation mixture contained $100 \mu$ of anti-Glc $\mathrm{RED}_{\mathrm{R}}-\mathrm{LDL}$ serum (initial dilution $1: 5,000), 100 \mu 1$ of $\mathrm{Glc}_{\mathrm{RED}}$-Hip-Lysine as a standard or a test sample which was reduced with $\mathrm{NaBH}_{4}$ as described later and $300 \mu 1$ of assay buffer $(50 \mathrm{mmol} / 1 \mathrm{PBS}, \mathrm{pH} 7.4$ containing $0.15 \%$ gelatin and $0.01 \% \mathrm{NaN}_{3}$ ). The mixture was incubated for $24 \mathrm{~h}$ at $4{ }^{\circ} \mathrm{C}$ and then ${ }^{125} \mathrm{I}-\mathrm{Glc}_{\mathrm{RED}}-\mathrm{BSA}(100 \mu \mathrm{l}$ about $10,000 \mathrm{cpm})$ was added and incubation was continued for $24 \mathrm{~h}$. Volumes of $100 \mu \mathrm{l}$ of anti-rabbit IgG goat serum (1:10 dilution) (Eiken Immunochemical, Tochigi, Japan) and normal rabbit serum (1:50 dilution) were added to the mixture. After further incubation for $24 \mathrm{~h}$ at $4^{\circ} \mathrm{C}$, the mixture was centrifuged at $1800 \mathrm{~g}$ for $30 \mathrm{~min}$ at $4^{\circ} \mathrm{C}$ and radioactivity of the precipitate was counted in a gamma counter. Figure 1 shows the displacement curves of ${ }^{125} \mathrm{I}-\mathrm{Glc}_{\mathrm{RED}}$-BSA by $\mathrm{Gl}_{\mathrm{RED}}$-Hip-Lysine and several other materials used to prepare glycated proteins, such as sorbitol, glucose, lysine and native protein. The lowest detectable concentration of $\mathrm{Glc}_{\mathrm{RED}}$-Hip-Lysine was $13.7 \mathrm{nmol} / 1$, as estimated from the concentration that produced a response of 2SD above the zero-dose response.

\section{Precision}

Two samples with low and high concentrations of glycated protein were measured 10 times, in duplicate, during a single analytical run to determine the within-assay variation. For evaluating the betweenassay variation, we measured samples in duplicate in 10 successive analytical runs. For samples with low and high concentrations of glycated protein, the within-assay variations were 5.9 , and $4.4 \%$, and the between-assay variations were 6.4 and $5.2 \%$, respectively.

\section{Recovery studies}

Several concentrations of $\mathrm{Glc}_{\mathrm{RED}}$-HSA were added to serum samples reduced with $\mathrm{NaBH}_{4}$. The reduction of serum samples was done as follows; $8 \mathrm{mg} \mathrm{NaBH}$ was added to each $\mathrm{ml}$ of serum and the mix- 
Table 1. Body weight, blood glucose and $\mathrm{HbA}_{1 \mathrm{c}}$ in weeks 0 and 12 in normal rats and insulin-treated (STZ+Ins) and untreated (STZ) rats with streptozotocin-induced diabetes

\begin{tabular}{|c|c|c|c|c|c|c|}
\hline \multirow[b]{2}{*}{ Week } & \multicolumn{2}{|c|}{ Body weight (g) } & \multicolumn{2}{|c|}{ Blood glucose $(\mathrm{mmol} / \mathrm{l})$} & \multicolumn{2}{|c|}{$\mathrm{HbA}_{1 \mathrm{c}}(\%)$} \\
\hline & 0 & 12 & 0 & 12 & 0 & 12 \\
\hline Normal & $321 \pm 9.7$ & $554 \pm 36.5^{\mathrm{d}}$ & $7.7 \pm 2.66$ & $9.4 \pm 0.59$ & $1.3 \pm 0.68$ & $0.9 \pm 0.18^{\mathrm{d}}$ \\
\hline STZ+ Ins & $308 \pm 20.5$ & $417 \pm 35.9^{\mathrm{a}, \mathrm{d}}$ & $6.6 \pm 0.91$ & $25.6 \pm 1.20^{\mathrm{a}, \mathrm{d}}$ & $1.2 \pm 0.12$ & $2.4 \pm 0.24^{\mathrm{a}, \mathrm{d}}$ \\
\hline STZ & $311 \pm 13.6$ & $356 \pm 25.6^{\mathrm{a}, \mathrm{c}, \mathrm{e}}$ & $8.8 \pm 1.65$ & $27.2 \pm 1.54^{\mathrm{a}, \mathrm{d}}$ & $1.2 \pm 0.14$ & $3.7 \pm 0.45^{\mathrm{a}, \mathrm{b}, \mathrm{d}}$ \\
\hline
\end{tabular}

Blood glucose and $\mathrm{HbA}_{1 \mathrm{c}}$ were determined by the ways as described in Materials and methods. All values represented as mean $\pm \mathrm{SD}$. ${ }^{\mathrm{a}} \mathrm{vs}$ normal $(p<0.01) ;{ }^{\mathrm{b}}$ vs STZ + Ins $(p<0.01) ;{ }^{\mathrm{c}}$ vs STZ + Ins $(p<0.05) ;{ }^{\mathrm{d}}$ vs week $0(p<0.01) ;{ }^{\mathrm{e}}$ vs week $0(p<0.05)$.

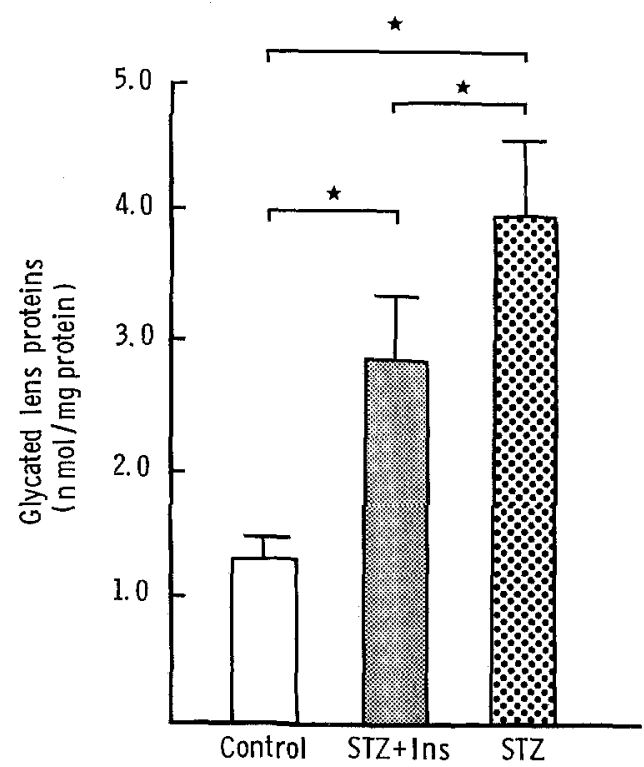

Fig. 3. Mean concentrations of glycated protein in the lens of control $\square(n=5)$, insulin treated $2(\mathrm{STZ}+\mathrm{Ins}, n=4)$ and untreated streptozotocin-induced diabetic $\$$ (STZ, $n=5$ ) rats determined by radioimmunoassay (RIA). Vertical bars represent $\mathrm{SD}$. $\star p<0.01$

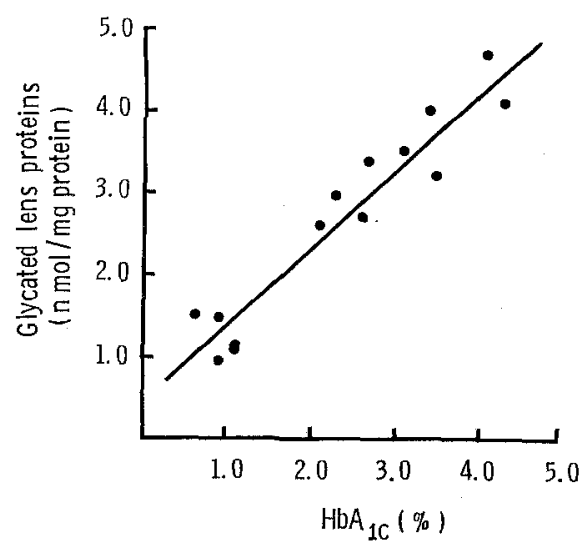

Fig. 4. Correlation of the amount of glycated protein in the lens with the $\mathrm{HbA}_{1 \mathrm{c}}$ level at the end of the experiment (12 weeks). Points represent values for individual animals $(r=0.957, p<0.001$, $y=0.96 \mathrm{x}+0.45) . \mathrm{HbA}_{1 \mathrm{c}}$ was measured by the high performance liquid chromatography method as described in Materials and methods

ture was incubated for $30 \mathrm{~min}$ at $37^{\circ} \mathrm{C}$; subsequently, the reaction was stopped by $0.5 \mathrm{ml}$ of $5 \%$ acetic acid and the mixture was diluted with the buffer. The average of analytical recovery of the glycated protein added to serum samples was $110.6 \%(90.5 \%-126.7 \%)$. When three reduced serum samples with low, medium and high concentration of glycated protein were diluted two- and four-fold with the buffer, the dilution-corrected glycated protein values were those expected (Fig. 2).

\section{Analyses}

Each lens was thawed and decapsulated. The lens tissue was solubilised by the method of Lee et al. [4] with a slight modification. Briefly, the tissue was solubilised in $2 \mathrm{ml}$ of $0.05 \mathrm{~N}$ sodium hydroxide by incubation at $40^{\circ} \mathrm{C}$ for $2 \mathrm{~h}$ with stirring. The mixture was neutralised with hydrochloric acid, and the neutralised solution was reduced with $\mathrm{NaBH}_{4}$ in the same way as described above. Then the reduced mixture was diluted $(1: 20)$ with the buffer, and used for determination of glycated protein by RIA as described above. A portion of the neutralised solution was used for protein determination by the method of Lowry et al. [10]. The recovery of $\mathrm{Glc}_{\mathrm{RED}}$-Hip-Lysine treated in the same way as the lens tissue was approximately $50 \%$. Blood glucose was measured by the glucose oxidase method and $\mathrm{HbA}_{1 \mathrm{c}}$ by high performance liquid chromatography. All values are expressed as mean $\pm S D$.

\section{Statistical analysis}

Statistical significance was analysed by Student's t-test.

\section{Results}

Table 1 shows the body weights and blood glucose and $\mathrm{HbA}_{1 \mathrm{c}}$ levels of the experimental groups. In week 0 , there were no significant differences in the values of any of these parameters in the three groups. Untreated diabetic rats (STZ group) gained little weight during the experiment, while diabetic rats treated with insulin (STZ + Ins group) gained appreciable weight, although their mean non-fasting blood glucose concentration was as high as that of the STZ group. The differences in the mean $\mathrm{HbA}_{1 \mathrm{c}}$ levels in the three groups in week 12 were statistically significant $(p<0.01)$. As shown in Figure 3, significant differences $(p<0.01)$ were also found in the mean concentrations of glycated protein in the lenses in the three groups (STZ, 3.92 \pm $0.52 \mathrm{nmol} / \mathrm{mg}$ protein; STZ $+\mathrm{Ins}, 2.94 \pm 0.36 \mathrm{nmol} / \mathrm{mg}$ protein; control, $1.23 \pm 0.22 \mathrm{nmol} / \mathrm{mg}$ protein). The concentrations of glycated protein in the lenses of individual rats were well correlated with their $\mathrm{HbA}_{1 \mathrm{c}}$ levels in week 12 (Fig. $4 ; r=0.957 y=0.96 \mathrm{x}+0.45, p<0.001$ ). 


\section{Discussion}

In the present study we developed a RIA for measuring glycated protein. The antibody obtained in this work was not specific for reduced glycated bovine LDL, which was used as an antigen, since it also bound to reduced glycated derivatives of a variety of other proteins, including bovine serum albumin and human serum albumin (data not shown). Judging from these results and the finding that it reacted with glucitol-lysine but not with any of the materials used for preparing glycated protein, we concluded that it was specific for the glucitol-lysine residue. This method of immunoassay of glycated proteins has the advantage of being sensitive and specific, and suitable for use with large numbers of samples. But it has the disadvantage of showing little reactivity with products of nonreductive glycation, which are believed to be the only forms of ketoamine and hemiketal Amadori protein adducts in the body. Therefore, before RIA, these compounds must be reduced with $\mathrm{NaBH}_{4}$ to glucitollysine, which the antibody specifically recognises.

Our results obtained by this RIA showed that glycation of lens proteins is significantly greater in diabetic rats than in nondiabetic control rats. This is consistent with the findings of others $[4,5]$ obtained by different analytical methods. Moreover, our values for glycated protein in the lens are similar to those obtained by Lee et al. [4]. There has been no report of the relation of the degree of glycation of lens proteins to the severity of diabetes mellitus. Our data showed a significant correlation between glycation of lens protein and the level of $\mathrm{HbA}_{1 \mathrm{c}}$ in experimental animals. This fact indicates that the glycation of lens protein and haemoglobin are correlated, or, in other words, that glycation of lens protein depends on the severity of diabetes mellitus. This explains why the amount of glycated protein in the lenses of diabetic rats treated with insulin was intermediate between those of normal rats and untreated diabetic rats.

Lens crystallin, a structural protein of the lens, has a much longer life-span than other proteins [11], and accordingly accumulates glycation products for a long period, even though the susceptibility of amino groups of this protein for glucose are weaker than those of other proteins such as albumin [12]. The $\mathrm{HbA}_{1 \mathrm{c}}$ levels in normal rats were approximately a quarter of those in man. These results are comparable with those reported by Rendell et al. [13]. The lower level in rats might be due to lower permeability of glucose [14] and a shorter life-span of rat erythrocytes [15]. The pathogenesis of cataract formation in diabetes is still controversial $[4,5,7,16,17]$. But if glycation of lens crystallin proteins has a role in the development of diabetic cataract, our finding that glycation of lens protein in diabetic rats increases in proportion to the severity of their diabetic state indicates that diabetes should be kept under control to prevent cataract formation. Our
RIA for precise and specific determination of the glycated proteins should be helpful in discovering the causes of diabetic complications.

Acknowledgements. The authors are indebted to Dr. E. Ichihara for her careful reviewing the manuscript, and to Mrs. T. Iwami for her excellent clerical work.

\section{References}

1. Mayer TK, Freedman ZR (1983) Protein glycosylation in diabetes mellitus: a review of laboratory measurements and of their clinical utility. Clin Chim Acta 127:147-184

2. Kennedy L, Baynes JW (1984) Non-enzymatic glycosylation and the chronic complications of diabetes: an overview. Diabetologia 26: $93-98$

3. Bunn HF (1981) Evaluation of glycosylated hemoglobin in diabetic patients. Diabetes 30:613-617

4. Lee JH, Shin DH, Lupovitch A, Shi DX (1984) Glycosylation of lens proteins in senile and diabetes mellitus. Biochem Biophys Res Commun 123: 888-893

5. Mandel SS, Shin DH, Newman BL, Lee JH, Lupovitch A, Drakes GHN (1983) Glycosylation in vivo of human lens capsule (basement membrane) and diabetes mellitus. Biochem Biophys Res Commun 117: 51-56

6. Monnier VM, Stevens VJ, Cerami A (1979) Nonenzymatic glycosylation, sulfhydryl oxidation, and aggregation of lens proteins in experimental sugar cataracts. J Exp Med 150: 1098-1107

7. Chiou SH, Chylack Jr LT, Bunn HF, Kinoshita JH (1980) Role of nonenzymatic glycosylation in experimental cataract formation. Biochem Biophys Res Commun 95: 894-901

8. Curtiss LK, Witztum JL (1983) A novel method for generating region-specific monoclonal antibodies to modified proteins. J Clin Invest 72: 1427-1438

9. Hunter WH, Greenwood FA (1962) Preparation of iodine-131 labelled human growth hormone of high specific activity. Nature 194: 495-496

10. Lowry OH, Rosebrough NJ, Farr AL, Randall RJ (1951) Protein measurement with the Folin phenol reagent. J Biol Chem 193: $265-275$

11. Hoenders HJ, Bloemendal H (1983) Lens proteins and aging. $J$ Gerontol 38: 278-286

12. Liang JN, Hershorin LL, Chylack Jr LT (1986) Non-enzymatic glycosylation in human diabetic lens crystallins. Diabetologia 29: 225-228

13. Rendell M, Stephen PM, Paulsen R, Valentine JL, Rasbold K, Hestorff T, Eastberg S, Shint DC (1985) An interspecies comparison of normal levels of glycosylated hemoglobin and glycosylated albumin. Comp Biochem Physiol 81: 819-822

14. Higgins PJ, Garlick RL, Bunn HF (1982) Glycosylated hemoglobin in human and animal red cells. Diabetes 31: 743-748

15. Belcher EH, Harriss EB (1959) Studies of red cell life span in the rat. J Physiol 146: 217-234

16. Stevens VJ, Rouzer CA, Monnier VM, Cerami A (1978) Diabetic cataract formation: potential role of glycosylation of lens crystallins. Proc Natl Acad Sci USA 75: 2918-2922

17. Pande A, Garner WH, Spector A (1979) Glucosylation of human lens protein and cataractogenesis. Biochem Biophys Res Commun 89: $1260-1266$

Received: 21 October 1987

and in revised form: 11 February 1988

Dr. M. Yano

Department of Laboratory Medicine

Tokushima University Medical. School

Kuramoto-cho, 3-chome, 18-15

Tokushima 770

Japan 